\title{
RELEVANSI PENDIDIKAN KARAKTER IBNU MISKAWAIH TERHADAP PENDIDIKAN ERA MODERN
}

\author{
Khairul Huda ${ }^{1}$, Fita Ratu Prilia ${ }^{2}$ \\ 1,2Universitas Islam Negeri Sunan Kalijaga Yogyakarta \\ ${ }^{1}$ Email: hud.uinsk@gmail.com \\ 2Email: ratuprilia04@gmail.com
}

\begin{abstract}
Abstrak: Tujuan penelitian artikel ini adalah untuk mengetahui; konsep pendidikan karakter perspektif Ibnu Miskawaih dan relevansi terhadap era modern. Penelitian ini menggunakan library research dengan metode analisis content analisys. Hasil penelitian menunjukkan bahwa dalam membentuk karakter, Ibnu Miskawaih melakukan penerapan melalui empat hal. Namun, yang lebih ditekankan adalah melalui pembiasaan dan latihan, karena dua metode ini dilakukan secara terus-menerus dan berulang-ulang. Ibnu Maskawaih menekanankan pendidikan karakter dalam dunia pendidikan hendaknya dilakukan sejak dini dan diajarkan secara berkesinambungan melalui peran lingkungan keluarga, pendidikan, dan masyarakat. Jika dikaitkan dengan pendidikan saat ini konsep pendidikan karakter Ibnu Miskawaih memiliki relevansi dengan Undang-Undang Sisdiknas No 20 tahun 2003 serta pilar karakter yang bertujuan agar peserta didik tidak hanya dituntut untuk cerdas, tetapi juga mempunyai kepribadian dan akhlak mulia.
\end{abstract}

Kata Kunci: Pendidikan Karakter, Ibnu Miskawaih

Title: The Concept of Character Education in the Perspective of Ibn Miskawaih and the Relevance of Character Education in the Modern Era

Abstract: The purpose of this research is to find out; the concept of character education in the perspective of Ibn Miskawaih, and the relevance of character education in the modern era. This research is library research with content analysis method. The results showed that in shaping character, Ibn Miskawaih implemented four things. However, what is more emphasized is through habituation and practice, because these two methods are carried out continuously and repeatedly. Ibnu Maskawaih emphasizes character education in the world of education which is carried out from an early age and tanght through the role of family, education, and society. If with current education the concept of Ibn Miskawaib's character education has relevance to the National Education System Law No. 20 of 2003 as well as the character pillar which aims so that students not only learn to be intelligent, but also bave noble personalities and morals.

Keywords: Character Education, Ibnu Miskawaih 


\section{PENDAHULUAN}

Di Indonesia, salah satu langkah dan bukti keseriusan pemerintah dalam rangka upaya pengembangan Sumber Daya Manusia (SDM) adalah dengan memberikan ruang dan perhatian besar pada aspek karakter dalam Sistem Pendidikan Nasional. ${ }^{1}$ Bukan hanya itu, pemerintah juga telah menegaskan hal tersebut lewat Rencana Pembangunan Jangka Panjang(RPJP) bahwa untuk mewujudkan masyarakat Indonesia yang berakhlak mulia, bermoral, beretika, berbudaya, dan beradab yang senantiasa berlandaskan pada nilai-nilai Pancasila, yaitu dapat dilakukan dengan memperkuat jati diri dan karakter bangsa melalui pendidikan. $^{2}$ Oleh karena itu, dalam Sistem Pendidikan Nasional(SISDIKNAS), pendidikan karakter sudah sejak lama dikembangkan pada setiap jenjang satuan pendidikan, mulai dari tinggat usia dini hingga sekolah menengah atas sebagai bentuk implementasi dari tujuan pendidikan nasional. ${ }^{3}$

Dalam dunia pendidikan Islam, berbicara tentang pendidikan karakter bukanlah sesuatu hal yang baru, karena pada umumnya pendidikan karakter dapat dipahami sebagai pendidikan akhlak. Menurut Imam Al-Ghazali, karakter mengarah kepada akhlak yang berarti sikap spontanitas yang dimiliki oleh manusia, dan juga berkaitan dengan perbuatan yang melekat pada diri manusia tanpa dipikirkan lagi ketika ingin bersikap. ${ }^{4}$ Jadi pada dasarnya, karakter merupakan sebuah sifat yang telah menyatu dalam pikiran dan perasaan seseorang yang menjadi pembeda antara manusia yang satu dengan yang lain. Sementara itu, pendidikan karakter dapat dipahami sebagai sebuah upaya menanamkan nila-nilai yang mendasar dalam diri individu dengan jalan pendidikan, berdasarkan pengalaman, pembiasaan, peraturan, lingkungan pendukung, dan pengorbanan menyesuikan dengan nilai-nilai yang ada dalam diri individu sebagai sebuah pondasi dalam bersikap, berpikir, dan berperilaku baik dalam keadaan sadar dan secara bebas. ${ }^{5}$

Terdapat beberapa tokoh muslim yang menjelaskan tentang karakter. Misalnya seperti Al-Farabi mengungkapkan bahwa akhlak yang baik akan muncul apabila adanya pengawasan dari dalam diri secara terus-menerus, sehingga pendidikan haruslah mengarah pada bimbingan terhadap akhlak, proses penyampaian materi pelajaran yang diberikan jika mengarah pada sebuah keburukan segera mungkin dilakukan pencegahan. Pendapat lain oleh Az-Zarnuji bahwa pendidikan tidak hanya bentuk ketaatan kepada Tuhan, tetapi tujuan

\footnotetext{
1 Nanda Ayu Setiawati, "Pendidikan Karakter," dalam Sebagai Pilar Pembentukan Karakter Bangsa: Prosiding Seminar Nasional Tabunan, Fakultas Ilmu Sosial Universitas Negeri Medan, 2017, hlm. 348.

2 Nopan Omeri, "Pentingnya pendidikan karakter dalam dunia pendidikan," Manajer Pendidikan 9, no. 3 (2015), hlm. 464.

3 Sri Haryati, "Pendidikan Karakter dalam Kurikulum 2013," lihat http://lib. untidar. ac. id/wpcontent/uploads/2017/01/Pendidikan-Karakter-dalam-kurikulum.pdf, 2017.

${ }^{4}$ Ani Nur Aeni, Pendidikan Nilai, Moral, dan Karakter, Pertama (Bandung: UPI Press, 2018). hlm. 117.

5 Maragustam Siregar, "Filsafat Pendidikan Islam Menuju Pembentukan Karakter," Yogyakarta: Pascasarjana FITK UIN Sunan Kalijaga, 2018, hlm. 248.
} 
pendidikan juga berkaitan dengan persoalan pembentukan moral, pribadi, intelektual, dan kesehatan jasmani dan membentuk sikap mental dalam lingkungan masyarakat yaitu amar makruf nahyi munkar melalui rasa tanggung jawab akan kesejahteraan masyarakat. Dari beberapa penjelasan tersebut sejalan dengan Ibnu Miskawaih bahwa yang menjadi impian atau cita-cita pendidikan merupakan terciptanya pribadi yang susila, melalui watak yang terlahir dari sikap-sikap luhur dan berbudi pekerti yang mulia. ${ }^{6}$

Berbicara tentang pendidikan karakter, tentu berbeda dengan pendidikan moral. Pendidikan karakter memiliki makna yang luas dibandingkan dengan pendidikan moral, karena tidak hanya berkaitan dengan istilah benar dan salah, bahkan lebih dari itu karena pendidikan karakter menanamkan sebuah kebiasaan yang baik, yang menjadikan siswa memahami, dapat merasakan, dan mempunyai keinginan melakukan hal yang baik. Ratna Megawangi memiliki sudut pandang yang berbeda terkait dua hal tersebut. berkaitan dengan moral yaitu sebuah pemahaman yang dimiliki oleh individu dalam hal kebaikan atau keburukan, sementara berkaitan dengan karakter merupakan suatu tabiat yang dimiliki oleh seseorang secara langsung dapat dikuasai atau dikontrol oleh otak. ${ }^{7}$ Pendidikan karakter bukan hanya sebuah diskursus tetapi harus adanya identifikasi karakter sebagai sebuah petunjuk yang mampu mengidentifikasi karakter yang mendasar yang dijadikan sebagai pilar terhadap perilaku seseorang. ${ }^{8}$

Pada dasarnya manusia lahir membawa fitrah yang baik dari dalam dirinya yang akan dikembangkan kearah yang baik. Lewat pendidikan karakter, diharapkan menjadi wadah untuk membangun karakter anak bangsa yang berakhlak mulia seperti yang dicita-citakan. Pendidikan karakter merupakan upaya menanamkan nila-nilai yang mendasar dalam diri individu dengan jalan pendidikan, berdasarkan pengalaman, pembiasaan, peraturan, lingkungan pendukung, dan pengorbanan menyesuikan dengan nilai-nilai yang ada dalam diri individu sebagai sebuah pondasi dalam bersikap, berpikir, dan berperilaku baik dalam keadaan sadar dan secara bebas. ${ }^{9}$

Di era sekarang ini, bagian-bagian dalam kehidupan manusia telah terkontaminasi oleh kehidupan moderen. Selain itu, kemajuan ilmu pengetahuan dan teknologi telah mengantarkan manusia pada satu fase "krisis multidimensi", yaitu suatu fase dimana manusia tidak hanya dilanda dengan krisis ekonomi, tapi juga krisis moral yang berujung pada

\footnotetext{
${ }^{6}$ Ani Nur Aeni, Pendidikan Nilai, Moral, dan Karakter. hlm. 123.

7 Abdul Majid dan Dian Andayani, Pendidikan Karakter Perspektif Islam, Keempat (Bandung: PT Remaja Rosdakarya, 2017). hlm. 14.

8 Abdul Majid dan Dian Andayani. hlm. 41.

9 Maragustam, Filsafat Pendidikan Islam Menuju Pembentukan Karakter (Yogyakarta: Pascasarjana Fakultas Ilmu Tarbiyah dan Keguruan (FITK) UIN Sunan Kalijaga Yogyakarta, 2018). hlm. 248.
} 
terjadinya dekadensi nilai, diantaranya adalah tergerusnya nilai-nilai karakter. ${ }^{10} \mathrm{Hal}$ itu tentu berimplikasi terhadap tergerusnya karakter dan pedoman hidup manusia, yaitu berkaitan dengan nilai-nilai etika dan spiritual keagamaan, nilai-nilai luhur bangsa, nilai sosial kultural, dan nilai filsafat hidup. Era demikian tentu berdampak negatif terhadap sumber-sumber nilai kehidupan manusia, bahkan cenderung menjauhkan manusia dari nilai-nilai agama sebagai pedoman pokok hidupnya. ${ }^{11}$

Maka untuk menyikapi persolaan tersebut, upaya internalisasi pendidikan karakter dalam setiap individu sangat penting dilakukan, dan tidak hanya berfokus di lingkungan sekolah. Peran keluarga maupun masyarakat harus dioptimalkan agar mendukung adanya pelaksanaan program penanaman karakter dalam dunia pendidikan pada setiap satuan pendidikan sehingga menjadikan sebagai rutinitas yang dilakukan setiap hari baik di rumah dan lingkungan tempat tinggal. ${ }^{12}$ Bedasarkan persoalan diatas, maka penulis tertarik untuk mengeksplorasi lebih jauh tentang; Bagaimana konsep pendidikan karakter perspektif Ibnu Miskawaih? Apa tujuan pendidikan karakter perspektif Ibnu Miskawaih? Apa saja keutamaan pembinaan karakter perspektif Ibnu Miskawaih?, dan Bagaimana relevansi pendidikan karakter perspektif Ibnu Miskawaih terhadap era modern?

\section{METODE PENELITIAN}

Penelitian ini adalah library research atau kepustakaan dengan sumber data berdasarkan kajian pustaka (study literatur). Terdapat dua sumber yang akan dijadikan sebagai bahan analisis yaitu sumber primer dan sumber sekunder. Sumber primer yang digunakan dalam penelitian ini yaitu buku Menuju Kesempurnaan Akhlak yang merupakan terjemahan dari Tabdzib AlAkhlaq yang ditulis oleh Ibnu Miskawaih, yang diterjemahkan oleh Helmi Hidayat. Sedangkan, sumber sekunder yang digunakan adalah buku Pendidikan Karakter Ibnu Miskawaih yang ditulis oleh M. Furqon Hidayatullah dan merupakan bagian dari buku yang berjudul Menuju Kesempurnaan Akhlak yang disusun oleh Ibnu Miskawaih, dan juga bukubuku, jurnal, sumber berita yang berkaitan dengan permasalahan yang akan dibahas. Metode yang telah digunakan adalah metode content analysis untuk menganalisis data yang didapatkan sebagai hasil penelitian. Metode ini digunakan untuk menganalisis secara mendalam terkait pendidikan karakter perspektif Ibnu Miskawaih dan relevansinya terhadap era modern.

10 Ach Maimun, Sayyed Hossein Nasr; Pergulatan Sains dan Spiritualitas Menuju Paradigma Kosmologi Alternatif, Pertama (Yogyakarta: IRCiSoD, 2015), hlm. 17.

${ }^{11}$ Maragustam, Filsafat Pendidikan Islam Menuju Pembentukan Karakter. hlm. 245-246.

12 Abdul Majid dan Dian Andayani, Pendidikan Karakter Perspektif Islam. hlm. 41. 


\section{TEMUAN DAN PEMBAHASAN}

\section{Biografi Singkat Ibnu Miskawaih}

Ibnu Miskawaih mempunyai nama lengkap Abu Ali Ahmad bin Muhammad bin Ya'qub bin Miskawaih dilahirkan pada tahun 330-421 H/941-16 Februari 1030 M, berasal dari Ray menetap di Isfahan dan meninggal pada tahun $421 \mathrm{H} / 1030 \mathrm{M}$ di Isfahan serta memiliki keahlian pada banyak bidang diantaranya bidang kimia, filsafat dan logika sejak lama, selain itu terkenal dengan panggilan Al-Khaniz (pustakawan) karena dipercayai memegang bukubuku Ibn Al-Amid dan Adhud Al-Daulah bin Suwaihi. ${ }^{13}$ Beliau juga terkenal sebagai ahli sejarah dan filsafat, selama perkembangan keilmuannya. Beliau, juga dikenal sebagai seorang moralis, penyair, dan banyak menekuni pengetahuan dibidang kimia dan juga berkaitan dengan filsafat. Ibnu Miskawaih lebih dikenal sebagai filosof akhlak. Selain itu, dirinya juga memiliki keahlian dan diakui keberadaannya sebagai pemikir muslim yang berpengaruh besar, dan menciptakan karya yang sangat diperhitungkan. Salah satunya adalah pemikirannya yang berkaitan dengan etika dan moral beliau cantumkan dalam tiga karya yang berjudul Tartib asSa'adah, Tahzib al-Akblah dan Jawidan Khirad. ${ }^{14}$

\section{Konsep Pendidikan Karakter Perspektif Ibnu Miskawaih}

Ibnu Miskawaih menyatakan bahwa karakter (khuluq) adalah keadaan suatu jiwa manusia. Suatu keadaan yang dimana jiwa bertindak tanpa adanya pertimbangan yang mendalam. ${ }^{15}$ Selain itu, Ibnu Miskawaih mengungkapkan bahwa pembentukan karakter dapat dilakukan melalui empat hal, diantaranya yaitu: ${ }^{16}$ Pertama, secara alamiah. Ibnu Miskawaih dalam bukunya mengatakan bahwa setiap manusia ada yang secara alami bermoral baik, meskipun jumlanya sangat sedikit, dan tidak akan pernah berubah menjadi bermoral buruk. Sebaliknya, ada juga diantara manusia yang secara alami bermoral buruk, dan tidak mengalami perubahan menjadi bermoral baik. Selain itu, juga pada sisi tengah-tengah, individu dapat berubah menjadi baik apabila dipengaruhi oleh lingkungan atau orang-orang baik, dan sebaliknya dapat menjadi buruk karena dipengaruhi oleh lingkungan atau orang-orang buruk, karena mengikuti segala bentuk apapun yang mereka lakukan. ${ }^{17}$

Ibnu Miskawaih mengungkapkan melalui pendidikan karakter peserta didik harus diarahkan menuju kesempurnaan, dalam hal ini pendidik menggunakan cara alami, dengan mendapatkan bagian yang ada dalam jiwa peserta didik yang sebelumnya telah muncul. Kemudian dilakukan perubahan serta dididik dengan cara bertahap, dengan mengamati

13 Abu Ali Ahmad Ibn Miskawaih, Menuju Kesempurnaan Akblak (Tabdzib Al-Akblaq), Cetakan Pertama (Bandung: Mizan, 1994). hlm. 29.

${ }_{14}$ M. Furqon Hidayatullah, Pendidikan Karakter Ibnu Miskawaih, Pertama (Sukaharjo: Dio Media, 2018). hlm. 10-12.

${ }^{15}$ Abu Ali Ahmad Ibn Miskawaih, Menuju Kesempurnaan Akblak (Tabdzib Al-Akblaq). 56.

${ }^{16}$ M. Furqon Hidayatullah, Pendidikan Karakter Ibnu Miskawaib. hlm. 18.

${ }^{17}$ Abu Ali Ahmad Ibn Miskawaih, Menuju Kesempurnaan Akblak (Tahdæib Al-Akblaq). 58. 
keberadaan potensi yang ada pada manusia dan menjalani proses perkembangan dari dalam diri manusia secara alamiah. ${ }^{18}$

Kedua, terbentuknya kebiasaan. Keadaan pada dasarnya menjadi sesuatu yang dipertimbangkan dan dipikirkan, dan dilakukan secara terus menerus berdasarkan praktek sehingga membentuk karakter. ${ }^{19}$ Kebiasaan adalah proses kegiatan yang dilakukan secara berulang-ulang. Kebiasaan berawal dari bentuk pembiasaan yang bersifat praktis artinya dilakukan dalam bentuk proses aktivitas, yang dapat menciptakan suatu kebiasaan dalam perilaku tertentu secara spontanitas, tanpa dilakukan perencanaan sebelumnya, sehingga dilakukan tanpa dipikirkan lagi. ${ }^{20}$ Selain itu, kebiasaan merupakan segala bentuk sesuatu yang dilakukan secara spontanitas, bahkan dilakukan tanpa berpikir, dan menjadi rutinitas yang dapat dilakukan secara berulang-ulang dan menjadi bagian yang tidak terpisahkan dari manusia. $^{21}$

Jika dikaitkan dengan pendidikan karakter pembiasaan dapat diarahkan pada terbentuknya sebuah sikap dan perilaku secara spontanitas yang dilakukan secara berulangulang berdasarkan proses pembelajaran, yang dilakukan secara besamaan atau secara perorangan. Sehingga diperoleh hasil berupa kompetensi atau kemampuan. Proses berkembangnya karakter dapat dilakukan melalui tahap pembiasaan baik direncanakan atau tidak direncanakan dalam menjalani kehidupan sehari-hari. Untuk mendapatkan karakter yang baik, dapat dilakukan dengan beberapa cara; ada tujuan yang akan dibiasakan, bentuk aktivitas tertentu yang akan dibiasakan, dilakukan secara rutin dalam waktu yang lama, aktivitas tersebut dilakukan hingga menjadi aktivitas yang otomatis, terpola, dan dilakukan tanpa berpikir, dan setelah terbiasa muncul kecanduan atau merasa ada sesuatu yang hilang jika tidak dilakukan. ${ }^{22}$

Dengan terbentuknya kebiasaan, maka karakter yang dibangun akan terpola dan tersistem perilakunya, karena telah menjadi kebiasaan. Kebiasaan yang terpola biasanya akan mengalami perubahan yang relatif permanen. Artinya kebiasaan yang telah terbentuk tidak akan mudah berubah begitu saja, karena kebiasaan yang terbentuk mengakibatkan apa yang dilakukan tanpa disadari, maka akan membentuk kebiasaan diselingi atau diintegrasikan halhal yang bersifat kognitif agar apa yang dilakukan tidak monoton. Sehingga apa yang dilakukan dan telah menjadi kebiasaan tetap dipahami dan disadari tentang akibat atau tujuan dari perilaku yang dilakukan. ${ }^{23}$ Pembiasaan dapat dilakukan dimulai dari sejak usia dini

18 Ahmad Busroli, "Pendidikan akhlak Ibnu Miskawaih dan Imam al-Ghazali dan relevansinya dengan pendidikan karakter di Indonesia," At-Tarbiyah: Jurnal Pendidikan Islam 10, no. 2 (2019): hlm. 77.

${ }^{19}$ Abu Ali Ahmad Ibn Miskawaih, Menuju Kesempurnaan Akblak. (Tabdzib Al-Akblaq). 56.

${ }^{20}$ M. Furqon Hidayatullah, Pendidikan Karakter Ibnu Miskawaih. hlm. 41.

${ }^{21}$ Felix Siauw, How to Master Your Habits (Jakarta: Al-Fath Press, 2014). hlm. 13.

22 M. Furqon Hidayatullah, Pendidikan Karakter Ibnu Miskawaih. hlm. 41-42.

${ }^{23}$ M. Furqon Hidayatullah. hlm. 42-43. 
dengan mengarahkan pada sikap dan perilaku yang baik. Dengan mencontohi apa yang dilakukan oleh orang yang menjadi panutan, diantaranya orang tua, guru, maupun orang yang dianggap menjadi seorang figur. Konsep pendidikan moral dan karakter yang sampai saat ini harus menjadi perhatian dan tidak bisa menjadi persoalan yang terabaikan. ${ }^{24}$

Ketiga, pendekatan latihan. Pendekatan latihan dapat diahami sebagai suatu proses aktivitas tertentu yang dilakukan dalam bentuk tersistematis dan secara terus-menerus untuk mencapai tujuan tertentu. ${ }^{25}$ Disamping pembiasaan latihan merupakan pendekatan dalam membentuk karakter. Terdapat tiga kata kunci dalam pembiasaan, yaitu: (a) Repetition atau, pengulangan yaitu melakukan berulang-ulang; (b) Process, memerlukan proses waktu dan dilaksanakan secara kontinyu; dan (c) Adaptation, kemampuan beradaptasi atau menyesuaikan. Pengulangan merupakan hal yang harus diperhatikan dalam pembiasaan, karena melakukan hal yang sama secara berulang ulang menjadikan seseorang akan terbiasa. Pengulangan memerlukan proses waktu dan dilakukan secara teratur dan konsisten, sehingga diperlukan ketekunan dan kesabaran, dengan memahami akan pentingnya aktivitas yang dilakukan. Dengan melakukan hal yang sama secara berulang-ulang, maka akan muncul adaptasi atau penyesuaian terhadap apa yang dilakukan secara berulang-ulang tersebut. Cepat atau lambat proses terbentuknya karakter seseorang sangat tergantung pada cepat atau tidaknya beradaptasi atau menyesuaikan dengan kondisi situasi baru yang sedang dihadapi. Oleh karena itu, kemampuan beradaptasi juga merupakan aspek atau unsur penting dalam membentuk kebiasaan yang pada akhrinya membentuk karakter. ${ }^{26}$

Dalam hal ini pendidikan karakter menjadi suatu hal yang harus diupayakan dan menjadi aktivitas dilakukan dengan cara berulang-ulang atau kontinyu untuk mengembangkan dan melakukan sesuatu dalam hal kebaikan. Adanya kesadaran dan upaya menjadi lebih baik merupakan langkah mulia dalam pendidikan karakter. Upaya perbaikan dalam pendidikan karakter memiliki keterkaitan dengan perubahan-perubahan yang meliputi suasana dan proses yang dilakukan dalam memahami dan mempelajari dengan menyatukan nilai-nilai karakter yang ada. Pendidikan karakter yang diterapkan sesuai dan benar dapat membangun salah satu faktor yang berkaitan dengan prestasi anak secara akademik, karena karakter mendasari aktivitas yang dilakukan misalnya, menumbuhkan dan mengembangkan semangat dan motivasi belajar untuk mendukung terciptanya perilaku belajar yang sungguh-sungguh. ${ }^{27}$

Keempaty, hukuman dan pukulan yang ringan. Berkaitan dengan hal Ibnu Miskawaih mengatakan bahwa dalam proses bimbingan untuk membentuk akhlak dengan cara hukuman dan pukulan ringan. Namun cara ini menjadi metode terakhir, jika cara lain tidak memberi

24 Busroli, "Pendidikan akhlak Ibnu Miskawaih dan Imam al-Ghazali dan relevansinya dengan pendidikan karakter di Indonesia." hlm. 77.

25 M. Furqon Hidayatullah, Pendidikan Karakter Ibnu Miskawaih. hlm. 27.

26 M. Furqon Hidayatullah. hlm. 37-39.

27 M. Furqon Hidayatullah. hlm. 39. 
pengaruh kearah yang lebih baik. Dengan metode ini Ibnu Miskawaih meyakini memberi pengaruh unsur jera untuk melakukan hal yang buruk untuk kedua kalinya agar menjadi manusia yang memiliki akhlak yang baik. Selain itu, melalui pendidikan akhlak dapat merubah akhlak yang buruk menjadi akhlak yang terpuji serta dengan proses latihan secara berulangulang. Pandangan tersebut sesuai dengan ajaran Islam, yang tercantum dengan jelas dan tegas menjelaskan bahwasannya melalui syariat agama bertujuan menegakkan dan membangun karakter manusia untuk memiliki karakter yang lebih baik. ${ }^{28}$

\section{Tujuan Pendidikan Karakter Perspektif Ibnu Miskawaih}

Tujuan utama pendidikan karakter menurut Ibnu Miskawaih, adalah menciptakan moral dari dalam diri individu yang menjadi sumber perbuatan dari apa yang telah dilakukan dan menjadi mudah dalam segala hal. Selain itu, Ibnu Miskawaih menyatakan bahwa bidang pembinaan karakter bertujuan menghasilkan tingkah laku manusia yang baik dan membawa pada perilaku terpuji, untuk membentuk manusia yang sempurna dan mengungkapkan kesempurnaan yang dimiliki manusia berada pada kenikmatan spiritual. Berdasarkan penjelasan diatas tujuan yang dimaksud oleh Ibnu Miskawaih mampu menghasilkan moral atas dasar sumber perbuatan, mencetak perilaku yang baik, dan kesempurnaan manusia berada pada kenikmatan spiritual. ${ }^{29}$

Pertama, moral sebagai sumber tindakan. Sebagaimana yang telah dikemukakan oleh Ibnu Miskawaih bahwa karakter berkaitan dengan jiwa atau bersumber pada jiwa, maka karakter harus dibangun dari dalam diri seseorang. Karena moral menjadi sebuah nilai dan norma yang dijadikan sebagai pegangan dalam pengotrol dan mengatur perilaku dan tindakkan yang dilakukan. Oleh sebab itu, akan menumbuhkan kesadaran seseorang untuk selalu melakukan kebaikan, dan memiliki kemampuan untuk bersikap, untuk menentukan hal yang baik dan buruk, dan hal yang benar dan yang salah. ${ }^{30}$ Keudan, kebahagiaan spiritual. Kebahagiaan hakiki adalah kebahagiaan yang bersifat spiritual, yaitu sesuatu yang berhubungan dengan kejiwaan (rohani dan batin). Menjadi spiritual dapat dinyatakan sebagai sesuatu yang berkaitan dengan kesadaran tentang keberadaan diri sendiri, kemampuan menjadi diri sendiri, dan menyelaraskan dengan keberadan jiwa. Akan lebih bermakna jika spiritual dikaitkan dengan agama, yaitu segala sesuatunya diorientasikan untuk mencari ridho Allah SWT, sehingga spiritual lebih bermakna karena meyakini terhadap apa yang dilakukan. Kebahagiaan spiritual pada dasarnya merupakan kebahagiaan tertinggi. Kebahagiaan spiritual memiliki ciri-ciri yang berbeda dengan kebahagiaan fisik. Dalam kebahagiaan spiritual seseorang merasa bahagia dan bermakna hidupnya justru ketika dalam posisi sebagai subjek

28 Busroli, "Pendidikan akhlak Ibnu Miskawaih dan Imam al-Ghazali dan relevansinya dengan pendidikan karakter di Indonesia." hlm. 77.

${ }^{29}$ M. Furqon Hidayatullah, Pendidikan Karakter Ibnu Miskawaih. hlm. 46.

${ }^{30}$ M. Furqon Hidayatullah. hlm. 46. 
bukan objek, memberi bukan diberi, menolong buka ditolong, mengabdi atau melayani bukan dilayani, memperhatikan bukan diperhatikan, memahami bukan dipahami orang lain, karena kebahagiaan spiritual (spiritual happiness) bersifat ruhani atau nurani. Oleh sebab itu, konsep karakter yang ditawarkan Ibnu Miskawaih memiliki pengertian yang lebih luas dan mendalam, karena menjadikan kebahagiaan spiritual bukan hanya pada tingkat tingkatan tinggi tetapi tingkatan sejati, dan menjadikan konsep karakter Ibnu Miskawaih berbeda dengan konsep karater yang lainnya. ${ }^{31}$

\section{Keutamaan Pembinaan Karakter Perspektif Ibnu Miskawaih}

Pertama, pentingnya pembinaan karakter. Pembinaan karakter bertujuan untuk menghasilkan tingkah laku manusia dalam melakukan kebaikan dan mengarah pada perilaku terpuji yang mempunyai kesempurnaan berdasarkan subtansi yang dimiliki oleh manusia itu sendiri, untuk mengangkat derajat manusia dari tercela menjadi manusia yang memiliki derajat yang mulia. ${ }^{32}$ Ibnu Miskawaih menyatakan bahwasannya pendidikan karakter menjadi sebuah hal paling utama dan terpenting dan dianggap sebagai salah satu bidang yang memberi pengaruh untuk membentuk generasi bangsa yang berakhlak mulia, karena bertujuan pada membentuk dan memperbaiki tingkah laku seseorang menjadi lebih baik. Pertimbangan utamanya adalah karena yang dididik adalah manusia. Sebagaimana yang dikatakan oleh Ibnu Miskawaih bahwa subtansi manusia mempunyai aktivitas yang khas yang tidak ada pada makhluk lainnya. Manusia merupakan makhluk yang memiliki kedudukan paling mulia diantara makhluk hidup lainnya, apabila individu tersebut tidak bertindak berdasarkan subtansinya, ibaratkan sebagai seekor hewan yang apabila tidak berperilaku layaknya seperti manusia. Karena posisi manusia adalah mulia, maka perlu pendekatan pendidikan yang tepat. Oleh sebab itu, berdasarkan pernyataan tersebut bahwa pentingnya pendidikan karakter kepada manusia diarahkan pada pertama, perilaku manusia yang baik; dan kedua pendekatan pendidikan yang tepat. ${ }^{33}$

Kedua, akhlak atau karakter utama. Menurut Ibnu Miskawaih terdapat lima karakter utama yang harus dibangun, diantaranya sebagai berikut: Pertama, kearifan. Bagian-bagian kearifan adalah pandai, ingat, berpikir, cepat memahami dan benar pemahamannya, jernih pikirannya, serta kemampuan belajar dengan mudah. (a) Pandai (al-dzaka) merupakan cepat mengembangkan kesimpulan-kesimpulan, serta mudahnya kesimpulan-kesimpulan tersebut dipahami oleh jiwa. (b) Ingat (al-dzikera) merupakan menetapnya gambaran tentang apa yang telah diserap jiwa atau imajinasi. (c) Berpikir (al-ta'aqul) adalah upaya mencocokkan objekobjek oleh jiwa dengan keadan sebenarnya dari objek-objek tersebut. (d) Kejernihan pikiran (shafaul al-dribni) merupakan kesiapan jiwa untuk menyimpulkan apa saja yang dikehendaki.

\footnotetext{
31 M. Furqon Hidayatullah. hlm. 47- 48.

32 Abu Ali Ahmad Ibn Miskawaih, Menuju Kesempurnaan Akblak (Tahdzib Al-Akblaq). hlm. 60-61.

33 M. Furqon Hidayatullah, Pendidikan Karakter Ibnu Miskawaih. hlm. 54.
} 
(e) Ketajaman dan kekuatan otak (jaudat al-dribni) adalah kemampuan jiwa untuk merenungkan pengalaman yang telah lewat. (e) Kemampuan belajar dengan mudah (subulat alta'allum) adalah kekuatan jiwa serta ketajaman dalam memahami sesuatu, sehingga dapat memahami masalah-masalah secara teoritis. ${ }^{34}$ Kedua, berani. Kebajikan yang menjadi bagian dari berani mencakup, kebesaran jiwa, ulet, tegar, tenang, tabah, menguasai diri, perkasa, serta ulet dalam bekerja. (a) Kebesaran jiwa, (b) Tegar (al-najdab), (c) Ulet (azzam al-bimmab), (d) Tenang, (e) Tabah, (f) Menguasai diri, (g) Perkasa, (h) Ulet dalam bekerja. ${ }^{35}$ Ketiga, dermawan. Kebajikan yang terdapat dalam sifat dermawan mencakup, murah hati, mementingkan orang lain, rela, berbakti, tangan terbuka. (a) Murah hati (al-karam) merupakan kecenderungan untuk mudah menginfakkan hartanya dijalan Allah yang berhubungan dengan hal-hal yang bermanfaat. (b) Mementingkan orang lain (al-itsar) adalah menahan diri dari hal yang diinginkan, demi memberikannya kepada orang lain yang menurutnya lebih berhak. (c) Rela (al-nail) adalah bergembira hati dalam berbuat baik dan suka pada perbuatan yang dilakukannya. (d) Berbakti (al-muwasab) dalah menolong teman atau orang yang berhak di tolong, dan memberi mereka uang dan makanan. (e) Tangan terbuka (al-samahab) adalah membelanjakan sebagin dari apa yang tidak boleh dibelanjakan. ${ }^{36}$ Keempat, adil. Bagian-bagian dari sifat adil yang dimaksud adalah sebagai berikut: (a) Bersahabat, (b) Bersemangat sosial, (c) Bersilaturrahmi, (d) Memberi imbalan, (e) Bersikap baik dalam kerja sama, (f) Jeli dalam memutuskan masalah, (g) Cinta kasih, (h) Beribadah, (i) Jauh dari rasa dengki, (j) Memberi imbalan yang baik walaupun diri sendiri ditimpa keburukan, (k) Berpenampilan lembut, (l) Berwibawa disegala bidang, (m) Menjauhi diri dari bermusuhan, (n) Tidak menceritakan hal yang tidak layak, (o) Mengikuti orang-orang yang berkata dengan benar, (p) Tidak berbicara tentang sesama muslim bila tidak ada kebaikannya, (q) Menjauhkan diri dari kata-kata buruk, (r) Tidak betah berucap kalau cuma akan menjatuhkan seseorang, (s) Tidak menjelek-jelekkan orang lain, ( $\mathrm{t}$ ) Tidak peduli pada perkataan orang pelit waktu berbicara di depan umum, (u) Baik yang tampak maupun yang tidak tampak, (v) Mendalami masalah seseorang yang perlu dibantunya, (w) Mengulang pertanyaan bila belum jelas. Berdasarkan uraian diatas karakter utama yang ungkapkan Ibnu Miskwaih bisa diperoleh melalui kemauan dan upaya yang membutuhkan waktu dan proses. ${ }^{37}$

\section{Relevansi Pendidikan Karakter Perspektif Ibnu Miskawaih di Era Moderen}

Pembentukan karakter merupakan faktor yang sangat penting untuk meningkatkan dan menghasilkan generasi penerus bangsa yang berkualitas, salah satunya melalui dunia pendidikan sebagai sarana yang dijadikan wadah untuk menyiapkan dan menciptakan individu

\footnotetext{
34 Abu Ali Ahmad Ibn Miskawaih, Menuju Kesempurnaan Akblak (Tabdzib Al-Akblaq). hlm. 46-47.

35 Abu Ali Ahmad Ibn Miskawaih. hlm. 48.

36 Abu Ali Ahmad Ibn Miskawaih. hlm. 49.

37 Abu Ali Ahmad Ibn Miskawaih. hlm. 49.
} 
berkualitas yang memiliki karakter dan moralitas yang kokoh, sehingga tidak mudah terpengaruhi oleh arus modernisasi. Dalam hal ini, letak urgensi pendidikan karakter Ibnu Miskawaih harus dikembangkan dalam dunia pendidikan saat ini, mengingat pentingnya pembentukan karakter untuk anak bangsa. ${ }^{38}$

Relevansi pandangan Ibnu Miskawaih tentang pendidikan karakter memiliki korelasi dengan era modern, berawal dari pandangan Ibnu Miskawaih tentang pendidikan karakter tercantum dalam pasal 1 Undang-Undang Sisdiknas No 20 tahun 2003 serta pilar karakter yang memiliki tujuan agar individu tidak hanya dibentuk untuk cerdas, tetapi juga mempunyai kepribadian dan akhlak mulia. Dengan demikian, pemikiran Ibnu Miskawaih memiliki relevansi dengan pendidikan era modern saat ini, menurutnya dalam kecerdasan harus berpedoman terhadap nilai luhur diantaranya adalah memiliki keimanan, berakhlak mulia, dan berasal dari nilai dalam ajaran agama Islam. ${ }^{39}$

Berdasarkan penerapannya pendidikan karakter diintegrasikan dengan memasukkan nilai pendidikan karakter dalam kurikulum pendidikan nasional. Implementasi pelaksanaan pendidikan karakter dilaksanakan secara integral dalam cakupan kurikulum tahun 2013, dan dicantumkan pada setiap mata pelajaran pada setiap jenjang pendidikan dengan penanaman karakter secara menyeluruh. Sehingga, konsep pendidikan karakter yang ditawarkan oleh Ibnu Maskawaih dapat dijadikan sebagai rujukan bagaimana pelaksanaan pendidikan karakter yang akan diterapkan khususnya dalam pendidikan Islam maupun pelaksanaan pendidikan nasional di Indonesia. Karakter yang diinginkan menjadi sebuah harapan untuk membentuk pribadi individu berlandaskan aturan agama dan budaya bangsa. ${ }^{40}$

Sejalan dengan penjelasan diatas, pemikiran Fazlur Rahman juga telah diterapkan di Indonesia yaitu, dengan adanya pembagian tingkat pendidikan antara pendidikan dasar, menengah dan perguruan tinggi. Dan sistem pendidikan tidak adanya lagi bentuk dualisme, serta dikotomi dalam sistem pendidikan. Berdasarkan standar isi kurikulum yang menyantumkan berbagai macam komponen yang dikaji dan memuat mata pelajaran. Dengan jelas kurikulum tahun 2013 telah mengupayakan melakui proses pengintegrasian nilai-nilai spiritualitas, sesuai dengan yang tercantum dalam kompetensi inti yang terdapat dalam kurikulum tersebut. Di era modernisasi pendidikan Islam memiliki relevansi dengan apa yang

38 Himayatul Izzati, "Pendidikan Islam (Studi Normatif Pendidikan Etika: Telaah Pemikiran Ibnu Maskawaih)," Jurnal Al-Mutaaliyab: Jurnal Pendidikan Guru Madrasab Ibtidaiyah 2, no. 1 (2017): hlm. 103.

${ }^{39}$ Mulkul Farisa Nalva, "Pendidikan Karakter Perspektif Ibnu Miskawaih," Jurnal PAI Raden Fatah 2, no. 1 (2020): hlm. 23.

40 Harpan Reski Mulia, "Pendidikan Karakter: Analisis Pemikiran Ibnu Miskawaih," Tarbawi: Jurnal Ilmu Pendidikan 15, no. 1 (2019): 39-51. hlm. 48. 
dirancang oleh pemerintah terkait sistem pendidikan di Indonesia. Selain itu, juga berkaitan dengan adanya kurikulum tahun 2013 yang mengutamakan pendidikan karakter. ${ }^{41}$

Dalam hal ini pendidikan karakter Islam menjadi salah satu yang harus diupayakan untuk membentuk karakter individu dengan model terintegrasi dalam bentuk kurikulum pendidikan. Dalam hal ini, dibentuk pendidikan karakter secara tersendiri yang dijadikan sebagai mata pelajaran pada setiap jenjang pendidikan, ataupun dicantumkan secara integral dalam setiap mata pelajaran yang akan dipelajari, juga dalam bentuk diluar proses pembelajaran atau menyatukan beberapa metode tersebut. Hal ini menunjukkan bahwa keberadaan pendidikan karakter mampu menyesuaikan akan kebutuhan individu beserta situasi yang ada. ${ }^{42}$ Berdasarkan penjelasan diatas menunjukkan bahwa konsep pendidikan karakter yang diungkapkan oleh Ibnu Miskawaih di bentuk berdasarkan pada keterkaitan dengan pendidikan akhlak. Dengan tujuan membentuk karakter yang menghasilkan sikap yang secara otomatis yang mengarah pada kebaikan, agar memperoleh kesempurnaan dan kebahagiaan yang abadi menuju sempurna. Jika peserta didik dapat diarahkan untuk mencapai kebijaksanaan Ibnu Miskawaih menganggap bahwa pendidik memiliki kedudukan yang sangat tinggi, karena mampu mengarahkan pada sebuah kesempurnaan sebagai manusia yang ideal. ${ }^{43}$

\section{Pembahasan}

Padangan Ibnu Miskawaih bahwa pendidikan karakter menjadi sebuah pendidikan terpenting dalam dunia pendidikan saat ini. Oleh sebab itu, menjadi salah satu bidang yang diperhitungkan keberadaannya, karena berpusat pada tingkah laku manusia agar menjadi baik. Ibnu Miskawaih menyatakan bahwa keadaan suatu jiwa manusia. Suatu keadaan yang dimana jiwa bertindak tanpa adanya pertimbangan yang mendalam. ${ }^{44}$ Pembentukan karakter pada individu menjadi faktor utama yang harus perhatikan dengan berdasarkan pada fitrah yang dimiliki manusia sehingga membentuk perilaku yang sesuai dengan fitrahnya. Perilaku yang baik ataupun buruk pada diri individu dapat merusak fitrah manusia karena dipengaruhi oleh lingkungan yang merupakan sarana melakukan interaksi dengan manusia yang lain berdasarkan hakikatnya. Oleh karena itu, peran keluarga dan lembaga pendidikan sangat dibutuhkan untuk bekerja sama menanamkan karakter pada seseorang. ${ }^{45}$

Berangkat dari penjelasan diatas dalam pandangan Ibnu Miskawaih, untuk membangun karakter manusia dalam lembaga pendidikan harus dimulai dari lembaga pendidikan sejak dini. Pendidikan karakter harus diajarkan kepada anak dengan cara terus menerus atau

41 Hadi Prayitno dan Aminul Qodat, "Konsep Pemikiran Fazlur Rahman Tentang Modernisasi Pendidikan Islam Dan Relevansinya Terhadap Pendidikan Islam Di Indonesia," Al-Fikri: Jurnal Studi dan Penelitian Pendidikan Islam 2, no. 2 (2019): hlm. 40-41.

${ }^{42}$ Mulia, "Pendidikan Karakter."hlm. 48-49.

43 Mulia. hlm. 49.

${ }_{44}^{4}$ M. Furqon Hidayatullah, Pendidikan Karakter Ibnu Miskawaih. hlm. 18.

${ }^{45}$ Izzati, "Pendidikan Islam (Studi Normatif Pendidikan Etika."hlm. 94. 
berkesinambungan untuk menanamkan akhlak yang baik, agar tertanam dalam pikiran yang terapkan melalui aktivitas yang dilakukannya setiap hari. Konsep pendidikan karakter Ibnu Miskawaih, pendidikan karakter harus dilakukan dengan betahap dan berulang-ulang melalui pembiasaan dan latihan, diawali dari dalam lingkungan keluarga hingga lembaga pendidikan berdasarkan pada tingkat perkembangan dan kebutuhan anak dalam berpikir. ${ }^{46}$ Selain itu, konsep pendidikan karakter yang ditawarkan Ibnu Miskawaih dapat memberi pengaruh pada perkembangan khususnya Pendidikan Islam dewasa ini. Ibnu Miskawaih menekanankan konsep pendidikan karakter dalam dunia pendidikan seharusnya dilakukan sejak dini seperti yang dijelaskan sebelumnya. Ibnu Miskawaih mengungkapkan bahwa manusia dilahirkan dalam keadaan bersih atau fitrah, seiring dengan perkembangannya manusia dipengaruhi oleh lingkungan tempat dia tinggal, baik lembaga pendidikan ataupun lembaga lainnya. ${ }^{47}$

Sejalan dengan pandangan Ibu Miskawaih. Maragustam mengatakan pada dasarnya manusia membawa fitrah-fitrah yang baik (ahsan taqwin) yang dapat dikembangkan kearah yang baik. Namun dalam proses hidup manusia dilingkupi oleh berbagai gesekan lingkungan seperti, sosial media, sosio kultural, pendidikan, tradisi. Sehingga karakter manusia menjadi negatif tak terkontrol (tuna karakter). ${ }^{48}$

Perkembangan hidup manusia tidak lepas dari pengaruh yang baik maupun buruk, sehingga berdampak pada pembentukan karakter dengan menyaksikan sendiri bagaimana manusia menunjukan karakter yang dimilikinya pada manusia lain, berupa karakter baik atau sebaliknya. Bahkan ada karakter-karakter yang saling bertolak belakang, sehingga dapat mengetahui tingkatan karakter mulia dimiliki oleh manusia. Berulang kali Ibnu Miskawaih mengatakan bahwa, peran pendidik, atau orang tua sangat penting dalam mendidik karakter yang beraneka ragam tingkatannya untuk menanamkan karakter dalam diri anak untuk menjadi manusia yang mulia. Atas dasar keberagaman perkembangan manusia yang menjalani proses kehidupan. Ibnu Miskawaih menyatakan bahwa bidang pembinaan karakter bertujuan menciptakan manusia yang memiliki tingkah laku yang baik untuk menuju perilaku yang terpuji dan menjadi manusia sempurna serta menjelaskan tentang kesempurnaan manusia terletak pada kenikmatan spiritual. Berdasarkan uraian diatas dapat diketahui bahwa pendidikan karakter yang dimaksud oleh Ibnu Miskawaih bertujuan menghasilkan moral sebagai sumber perbuatan, mencetak perilaku yang baik, dan kesempurnaan manusia yang terletak pada kenikmatan spiritual. ${ }^{49}$

\footnotetext{
46 Izzati. hlm.104.

47 Izzati. hlm. 105.

48 Maragustam, Filsafat Pendidikan Islam Menuju Pembentukan Karakter. hlm. 254.

${ }^{49}$ M. Furqon Hidayatullah, Pendidikan Karakter Ibnu Miskawaih. hlm. 46.
} 


\section{KESIMPULAN}

Dari pembahasan diatas dapat disimpulkan, Ibnu Miskawaih menyatakan bahwa karakter (khuluq) adalah keadaan suatu jiwa manusia. Suatu keadaan yang dimana jiwa bertindak tanpa adanya pertimbangan yang mendalam. Dalam membentuk karakter Ibnu Miskawaih melakukan penerapan melalui empat hal, yaitu: secara alamiah, terbentuknya pembiasaan, pendekatan latihan, dan metode hukuman dan pukulan yang ringan. Namun, yang lebih ditekankan adalah melalui pembiasaan dan latihan, karena dua metode ini dilakukan secara berkelanjutan dan berulang-ulang. Ibnu Maskawaih menekanankan pendidikan karakter hendaknya dilakukan sejak dini dan diajarkan secara berkesinambungan pada individu dengan tujuan menanamkan nilai-nilai kebaikan, melalui peran orang tua, pendidik, ustadz, ulama, kiai (lingkungan keluarga, pendidikan, dan masyarakat). Maka dilakukan sedini mungkin agar bisa dilakukan pembaruan untuk menjadi manusia yang mulia.

Tujuan utama pendidikan karakter menurut Ibnu Miskawaih, yaitu menghasilkan moral sebagai sumber perbuatan atau tindakan, mengasilkan manusia yang memiliki tingkah laku yang berpedoman pada nila-nilai luhur sehingga memiliki perilaku terpuji, serta menjelaskan tentang kesempurnaan manusia terletak pada kenikmatan spiritual. Selain itu menurut Ibnu Miskawaih terdapat enam karakter utama yang harus dibangun, diantaranya, yaitu kearifan, sederhana, integritas, berani, dermawan, dan adil. Diantara karakter tersebut dapat dibangun melalui kemauan dan upaya. Perbaikan karakter dapat dilakukan dengan memperhatikan perkembangan karakter yang dapat memungkinan terjadi penyimpangan karena dipengaruh lingkungan. Karena berkembangnya akhlak sangat dipengaruhi oleh kecenderungan adanya akhlak yang baik maupun buruk, sehingga dalam pembinaan akhlak harus selalu ada pendampingan dan arah pengembangan akhlak agar tidak menuju pada akhlak yang tercela.

Relevansi konsep pendidikan karakter Ibnu Miskawaih berkaitan dengan era modern, berdasarkan pada Undang-Undang Sisdiknas No 20 tahun 2003 serta pilar karakter bertujuan agar peserta didik tidak hanya diharuskan untuk cerdas, tetapi juga harus memiliki kepribadian dan akhlak mulia. Selain itu, dicantumkan secara utuh dalam kurikulum tahun 2013 yang memuat pendidikan karakter. Yang artinya pada mata pelajaran yang akan diajarkan pada setiap tingkatan pendidikan harus menekankan pengembangan pada komponen penanaman karakter. Sehingga, konsep pendidikan karakter yang ditawarkan oleh Ibnu Miskawaih dapat dijadikan sebagai rujukkan pelaksanaan pendidikan yang menekankan pada pendidikan karakter dan mempunyai relevansi dengan perkembangan pendidikan saat ini, karena Ibnu Miskawaih mengatakan kecerdasan harus berpedoman pada nilai-nilai luhur yang berdasarkan pada nilai-nilai ajaran agama Islam.

\section{DAFTAR PUSTAKA}

Abdul Majid dan Dian Andayani. Pendidikan Karakter Perspektif Islam. Keempat. Bandung: PT 
Khairul Huda dan Fita Ratu Prilia, Relevansi Pendidikan Karakter...

Remaja Rosdakarya, 2017.

Abu Ali Ahmad Ibn Miskawaih. Menuju Kesempurnaan Akblak (Tahdzib Al-Akblaq). Cetakan Pertama. Bandung: Mizan, 1994.

Ani Nur Aeni. Pendidikan Nilai, Moral, dan Karakter. Pertama. Bandung: UPI Press, 2018.

Busroli, Ahmad. "Pendidikan akhlak Ibnu Miskawaih dan Imam al-Ghazali dan relevansinya dengan pendidikan karakter di Indonesia." At-Tarbiyab: Jurnal Pendidikan Islam 10, no. 2 (2019): 71-94.

Felix Siauw. How to Master Your Habits. Jakarta: Al-Fath Press, 2014.

Gunawan, H. Pendidikan Islam Kajian Teoritis dan Pemikiran Tokoh. Bandung: Remaja Rosdakarya, 2014.

Haryati, Sri. "Pendidikan Karakter dalam Kurikulum 2013." lihat http:// lib. untidar. ac. id/wpcontent/uploads/2017/01/Pendidikan-Karakter-dalam-kurikulum. pdf, 2017.

Izzati, Himayatul. "PENDIDIKAN ISLAM (Studi Normatif Pendidikan Etika: Telaah Pemikiran Ibnu Maskawaih)." Jurnal Al-Mutaaliyah: Jurnal Pendidikan Guru Madrasah Ibtidaiyah 2, no. 1 (2017): 90-106.

Jalaluddin dan Usman S. Filsafat Pendidikan Islam; Konsep dan Perkembangan Pemikirannya. Jakarta: RajaGrafindo, 1999.

Maimun, Menjadi Guru Yang Di rindukan (Pelita Yang Menerangi Jalan Hidup Siswa). Yogyakarta: Kurnia Kalam Semesta, 2014.

Pratama, D. A. N. "Tantangan Karakter Di Era Revolusi Industri 4.0 Dalam Membentuk Kepribadian Muslim”. Al-Tanzim: Jurnal Manajemen Pendidikan Islam 03, no.01.

Purba, H. Pemikiran Pendidikan Islam Ibnu Miskawaih. MIQOT XXXIII, no. 2 (JuliDesember 2009

Rusmaini. "Manajemen Pendidikan Karakter di Lembaga Pendidikan Islam". Jurnal Of Islamic Education Management 3, no.1 (Juni 2017)

Sudin. Filosof Etika dan Sosial Islam Ibn Miskawaih. Yogyakarta: SUKA-Press, 2012.

Asyrofi, S. Beberapa Pemikiran Pendidikan. Malang: Aditya Media, 2012.

Usman. Filsafat Pendidikan Kajian Filosofi: Pendidikan Nabdlatul Wathan di Lombok. Yogyakarta: Teras, 2012.

M. Furqon Hidayatullah. Pendidikan Karakter Ibnu Miskawaih. Pertama. Sukaharjo: Dio Media, 2018.

Maimun, Ach. Sayyed Hossein Nasr; Pergulatan Sains dan Spiritualitas Menuju Paradigma Kosmologi Alternatif. Pertama. Yogyakarta: IRCiSoD, 2015.

Maragustam. Filsafat Pendidikan Islam Menuju Pembentukan Karakter. Yogyakarta: Pascasarjana Fakultas Ilmu Tarbiyah dan Keguruan (FITK) UIN Sunan Kalijaga Yogyakarta, 2018.

Mulia, Harpan Reski. "Pendidikan Karakter: Analisis Pemikiran Ibnu Miskawaih." Tarbawi: Jurnal Imu Pendidikan 15, no. 1 (2019): 39-51.

Nalva, Mulkul Farisa. "PENDIDIKAN KARAKTER PERSPEKTIF IBNU MISKAWAIH." Jurnal PAI Raden Fatah 2, no. 1 (2020): 11-27.

Omeri, Nopan. "Pentingnya pendidikan karakter dalam dunia pendidikan." Manajer Pendidikan 9, no. 3 (2015).

Prayitno, Hadi, dan Aminul Qodat. "Konsep Pemikiran Fazlur Rahman Tentang Modernisasi Pendidikan Islam Dan Relevansinya Terhadap Pendidikan Islam Di Indonesia." Al-Fikri: Jurnal Studi dan Penelitian Pendidikan Islam 2, no. 2 (2019): 30-43.

Setiawati, Nanda Ayu. "Pendidikan Karakter." Dalam Sebagai Pilar Pembentukan Karakter Bangsa: Prosiding Seminar Nasional Tahunan, Fakultas Ilmu Sosial Universitas Negeri Medan, 
Jurnal Penelitian Keislaman Vol.17 No.1 (2021): 71-86

2017.

Siregar, Maragustam. "Filsafat Pendidikan Islam Menuju Pembentukan Karakter." Yogyakarta: Pascasarjana FITK UIN Sunan Kalijaga, 2018. 